\title{
Teaching English Literature to Digital Natives with special reference to Ernest Hemingway's The Old Man and the Sea
}

\author{
Justin James* \\ eLearning Coordinator, EFS/ESL/ICT Teacher and Teacher Trainer, English Language Center, \\ Nizwa College of Technology, Sultanate of Oman; justin.james@nct.edu.com
}

\begin{abstract}
This paper is an extension of the workshop titled Learning English Language, Literature and Critical thinking for Digital Natives I conducted at the UGC sponsored symposium on Learning English in the Glocalised World organized by the PG and Research Department of English, Vellalar College for Women (Autonomous), Erode, India on $24^{\text {th }}$ January 2019 for the PG Students and Research Scholars of the region. Digital Natives are the children who were born since the last two decades of the $20^{\text {th }}$ century when the world has been filled with computers, videogames, digital music players, cell phones, and myriads of technological toys and gadgets. The advent of the technological era has resulted in a dichotomy in the academic world which is the digital natives being taught by Digital Immigrant teachers i.e., the teachers who were born before the $1980 \mathrm{~s}$ and immigrated into the world of modern technology. There are many clashes between the approaches of the teachers and the preferred learning styles of the learners. To bridge these gaps between them, the use of Internet Communication Technology is a viable solution. The need for incorporating ICT is a necessity in English Literature courses too. Having understood the need for incorporating internet-based technology into teaching, this paper explores various ways in which literature teaching can be enhanced using ICT to meet the learning needs of the digital native students. English literature courses are offered in most Arts colleges and Universities in India. The growing demand for these courses among young generations is not just passion driven but also because of the worldwide career scope they offer in various fields including teaching.
\end{abstract}

Keywords: Blended Learning, Blogs, Digital Immigrants, Digital Natives, Films, Internet, Teaching Literature with Technology, ICT

\section{Introduction}

The current scenario at the higher education institutions in India is a juxtaposition of digital immigrant teachers and digital native learners. Many new resources, approaches and methodologies have emerged in the $21^{\text {st }}$ century world of education mainly due to advancements in computer and internet technologies. Being skilled and proficient in these technologies is essential for tertiary level teachers to cater to the needs of the learners who are talented in technology use and whose learning styles are completely different from those of the generations of their teachers. In this scenario, catering to the needs of the millennial students is a very challenging experience for the teachers who haven't assimilated into the era of technology.
To meet the requirements of the current academic beneficiaries, colleges and universities are trying to build a suitable framework by updating their syllabi, approaches, teaching methodologies and testing patterns. In the technologically advanced world with internet technology reaching every nook and corner of the world, such updating is not a big challenge. At the same time, it has become the cause of the growing perplexity among teachers regarding the methodology and materials they should adopt to teach the digital native students born equipped with computer and internet technologies.

When institutions try to integrate education technologies in their curriculum delivery, there arises a challenge of training the existing teachers who are Digital Immigrants i.e., the teachers who teach at the college and univer-

${ }^{*}$ Author for correspondence 
sity level born before the advent of the internet age and emigrated into the computer and the internet world $\frac{18}{}$. Teaching the digital natives is a challenge to this generation of teachers as their approaches and methodologies do not match the learning styles of the students. Prensky observes this situation as "very serious because the single biggest problem facing education today is that our Digital Immigrant instructors, who speak an outdated language [the outdated teaching methodology], are struggling to teach a population that speaks an entirely new language [new methodology in learning]" (2001).

In light of the situation discussed above, the integration of ICT is the pedagogical imperative of the current academic scenario. The term ICT refers to a diverse set of technological tools and resources used to communicate, and to create, disseminate, store and manage information ${ }^{5}$. As a result, digital immigrant teachers are required to have a better understanding of the characteristics of digital native learners and their ways of learning and to acquire necessary technical skills to be successful in teaching students adept in using technologies.

Many studies conducted in different parts of the world have proved that students show positive reactions to the implementation of technology in classrooms and that it helps a lot in students' engagement in Literature classrooms. According to AbdAlla, "the use of technology in teaching English Literature is considered the key to provide the present generation with the needed tools and resources to access, use and attain the expected skills of modern society" (2017). A study conducted by Apple reveals that "any disconnect between students' digital life and educational life matter because learning better involves engagement and engagement points to technology integration"

According to Light, "technology can help deepen and construct students' own knowledge regarding their critical thinking, problem-solving and creative thinking skills through a high-quality authentic learning environment, if effectively integrated" (2009). All these findings point to the fact that teachers should have the right attitude, approach and the necessary skill sets to exploit their students' interest and involvement in technology to make them successful and smart learners.

In this backdrop, the current paper attempts to describe the characteristics, learning styles and needs of digital native learners and to demonstrate how English Literature teachers can easily blend ICT in their teaching practices. Ernest Hemingway's The Old Man and the Sea, a commonly prescribed novel in almost all universities in India either at the undergraduate or postgraduate levels, is taken as a sample to exemplify how ICT can be integrated into teaching Literature.

\section{Who is a Digital Native?}

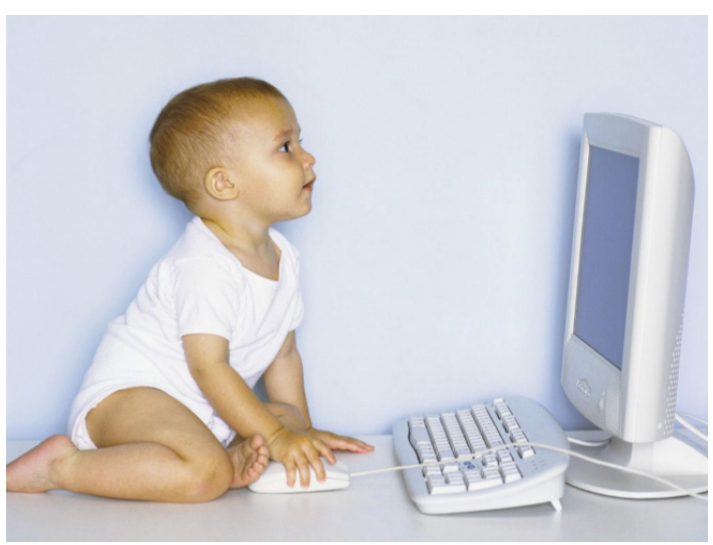

Figure 1: Digital Native (Scheer, 2012) ${ }^{22}$.

Digital Natives are the children who were born since the last two decades of the $20^{\text {th }}$ century into the world full of computers, videogames, digital music players, cell phones and myriads of modern technological toys and gadgets. They are the young people of today who are products of a new culture that has emerged because of the aggressive infiltration of digital technology into their lives. Marc Prensky named this generation as digital natives: "What should we call these "new" students today? ...the most useful designation I have found for them is Digital Natives. Our students today are all "native speakers" of the digital language of computers, video games and the internet" $\stackrel{\text {. }}{ }$.

\section{Characteristics, Learning Styles and Needs of Digital Natives}

The learning styles of students of the digital age are significantly different from those for whom our colleges were originally designed. Our colleges and instruction primarily based on lectures, textbooks, memorization and contentbased tests, are becoming increasingly out of sync with the world around them. Today's average college grads have spent fewer than 5,000 hours of their lives reading by the time they are 21, but they will have played more than 10,000 hours of video games, sent and received 250,000 emails and text messages, spent 10,000 hours talking on digital cell phones. Computer games, e-mails, the Internet, cell phones and instant messaging are integral parts of their lives ${ }^{18}$. In this context, what is wrong is that the world has changed and colleges have not. The world outside education has taken full advantage of the astounding power of new electronic tools and has moved beyond the idea of mass production and industrialization where knowledge was restricted to maintain production of materials needed 
for business and life. Today, we are in a completely new era of technologically driven mass communication where knowledge is unrestricted with the availability of limitless, customized and user-friendly technologies. In this age, knowledge is not restricted within the walls of academic institutions, books or within the realms of scholars. Therefore, academic institutions cannot afford to stop with the dissemination of information, as it is already available to the learners in various forms on the worldwide network as open resources. In this age, academic institutions are required to provide learners with learning skills, technical skills, communication skills and soft skills and teachers are required to function as facilitators guiding students through their search for knowledge by equipping them with necessary skills and a guide map for their easy navigation in the right direction. Therefore, adopting new approaches in teaching is incumbent today.

There is an important aspect of the digital age that educators should consider i.e., the impact that the online digital world has on the thinking patterns of young people. They have the ability to think and process information faster than the digital immigrants. They have grown up in an environment which is quite radically different from the environment that children had a few decades ago. Using devices like computers and myriads of other networked digital tools and social networking software are as natural to them as breathing. They are completely comfortable with powerful software tools that allow them to network with others to write essays and reports ${ }^{\underline{13}}$. Therefore, if we teach today's students as we taught yesterday's, we would rob them of tomorrow. We would rob them of tomorrow because we fail to equip them with the core set of skills they need to survive in today's workplace and for their lifelong learning and productive citizenship ${ }^{7}$.

The way to help them learn right is to change the way we teach and what we teach:

- Teachers/educators should learn to communicate in the language and style of the digital natives.

- Educators should carefully examine the content of the "traditional" curriculum (reading, writing, arithmetic, logical thinking and history) and select only the content that is essential for knowledge construction in the digital era.

- Educators should embed digital and technological content in their teaching. This does not mean just electronic hardware and software, but it also includes ethics, politics, sociology, languages and other content related to these.

- Educators should learn new content and teach using new technologies that digital natives are familiar with and that make sense to them.

- Educators should replace the traditional pedagogical language with contemporary, computer-aided terminology, consistent with digital native methodology. This should be applied to all subjects and at all levels of learning.

- Educators should think deeply and research into how to use computers and other digital tools in teaching in ways that help learners to instill the knowledge that needs to be internalized.

- Educators should use the skills of Digital Natives to guide their search for Digital Native methodologies that can help improve their effectiveness in teaching.

- The innovators and leaders in the field of embedding technology in teaching and learning should share and publicize their success stories.

- Educators should be open and imaginative about embedding "edutainment" in pedagogy.

In the worlds of Prensky, "If we accept that our role as pedagogues is to facilitate learning for our students, then we should appreciate that it is incumbent upon us to develop a good understanding of how they learn, as this will improve our pedagogical practice so that we can be more effective teachers by maximizing their learning 18 .

Educators of today, "... have to think in terms of the learning styles of the new generation students. This will give us an idea about the way we plan our curriculum and the methodology of delivering the curriculum ${ }^{25}$. The digital natives' norms for learning are:

- They prize freedom and freedom of choice.

- They love to customize things, make them their own.

- They are natural collaborators, who enjoy a conversation, not a lecture.

- They will scrutinize you and your organization.

- They insist on integrity and openness.

- They want to have fun, even at work and at school.

- They have a need for speed and speed is normal for them.

- They are innovators and for them, innovation is a part of life.

- They instinctively turn first to the internet to communicate, understand or learn. 


\section{Blending ICT with Current Teaching Practices}

\subsection{Internet Resources as an Aid in Teaching English Literature}

Internet resources can effectively complement conventional teaching practices. The word 'complement' here is important because technology cannot replace the teacher entirely. However, the use of ICT can bridge the gaps between traditional teaching modalities and learner needs. In most colleges and universities across the country, English literature is taught following the conventional teacher-centered methodology. Teachers spend a lot of time in lecturing about the plot, characters and themes of literary texts which are deemed dull and dreary by millennials. Learning literature, a content subject, is not easy for students have to master both the language and the content and therefore teachers should employ resources and approaches that excite and motivate students.

Internet resources can help in stimulating the process of learning. In English Literature classrooms, an engaging and interesting learning environment can be created using internet resources ${ }^{14}$. Teaching and learning literature is not easy as it is an open-ended subject which does not provide ideal answers and learning a literary text requires a higher level of comprehension, both explicit and implicit levels of comprehension. And students' comprehension can be increased multifold when the teaching materials include images, videos, and audios which are used effectively. In the words of Saunders, these pictures and sounds are "generally understood well and remembered easily" since "they are closely related to the way people see things in everyday life"20. This is highlighted through Saunders' three stages of human mental perception as illustrated in the figure given below:

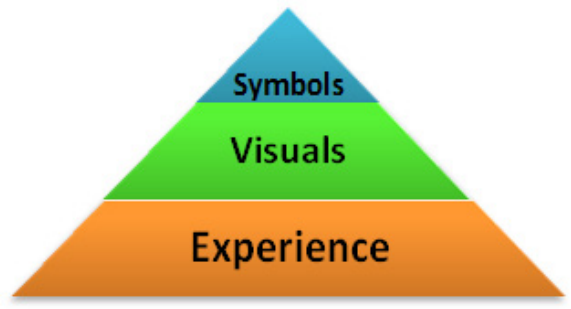

Figure 2: Stages of human mental perception (1974).

From this figure, it is clear that humans perceive the world through the symbols they see and the visual experience makes them understand abstract things better and retain them in their memory. This applies to learning literature as well. When a student is asked to read a literary text, he reads the words in the text and visualizes the events, settings, and attributes of characters as described in the text. The outcome of the two stages, reading and visualizing, is the creation of mental images which help the student to experience the artistic values of the text. In addition to reading, if the student gets to see some visuals related to the text in the form of pictures and movies, and in addition listen to the conversations in the movies, his experience and enjoyment of the text are enriched and his comprehension is enhanced ${ }^{6}$.

\subsection{Slide Share}

LinkedIn Slide Share is a hosting service for professional content that includes presentations, infographics, documents and videos. Slide Share is a great resource for literature teachers of today. Users can also upload content prepared by them privately or publicly in Power Point, Word, PDF or in any other open document format that can be viewed on the site using a smart mobile device anywhere, anytime.

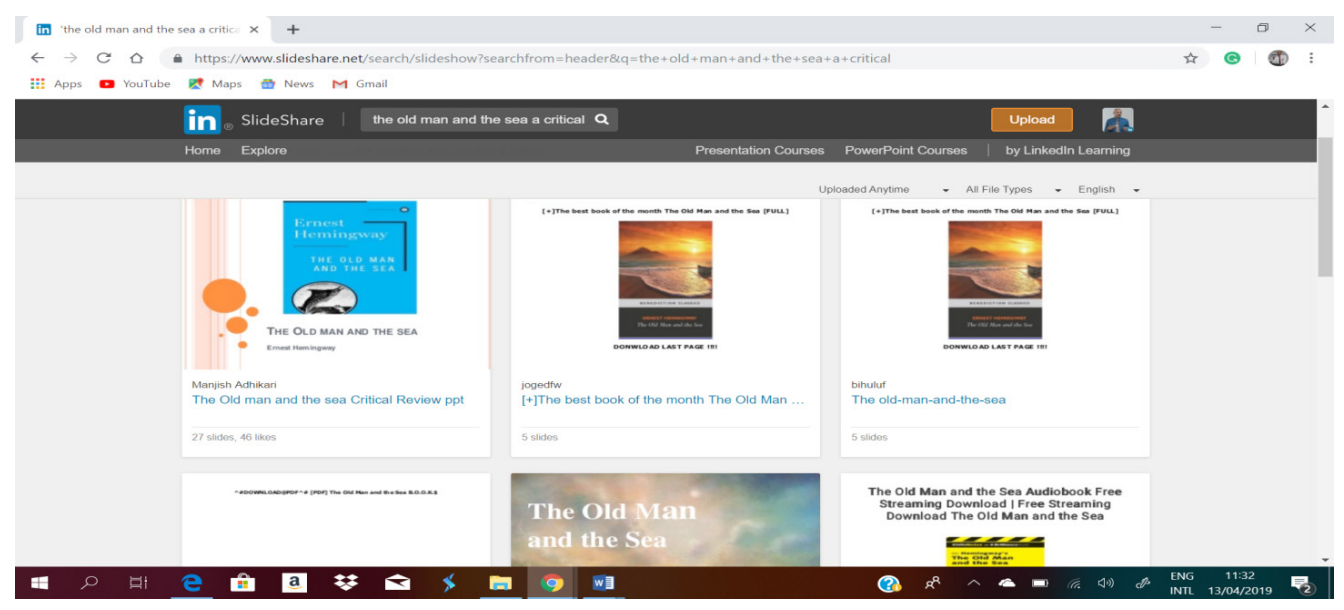

Figure 3: Screenshots - Slides on The Old Man and the Sea. 
Slide Share has many resources that help understand The Old Man and The Sea. Teachers can use these online slides in the classroom to discuss various aspects of the novel. Teachers should have first-hand knowledge/reading of the novel so that using the slides in the class becomes very easy. The resources include slides covering the entire text and the one that helps students prepare for the exam. The top five Slide Share resources on The Old Man and the Sea are given below:

- The Old Man and the Sea Critical Review by Mangish Adhikari.

- The Old Man and the Sea Advanced Exam Preparation by Andy Fisher.

- The Old Man and the Sea by Luciana Scher.

- The Old Man and the Sea as a tragedy by Umabahliya.

- The Old Man and the Sea book review by Qazi Faheem.

\subsection{Movies}

There are many movies based on the novel which can help in understanding and enjoying the novel better. These movies are currently available on YouTube. The most acclaimed movies on the novel are The Old Man and The Sea by Alexander Petrov made in 1999 using 26000 slides prepared on glass plates and then filmed. This was an experiment in showing the novel in an animated form and this is acclaimed as one of the greatest movies of that time on the novel. The next movie worth mentioning here is The Old Man and The Sea (1958) by John Sturges, Fred Zinnemann. Another recent movie that depicted the novel with its full grandeur is The Old Man and The Sea (1990) by Jud Taylor and the lead actor is Anthony Quinn. These movies can be watched from anywhere on YouTube on a smart mobile today.

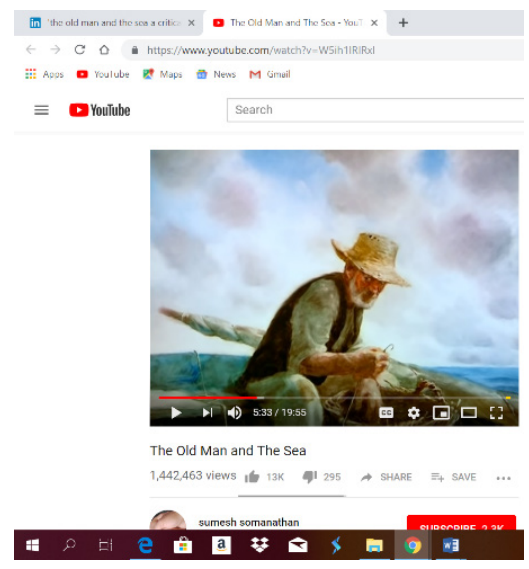

The Old Man and the Sea (1999) by Alexander Petrov.

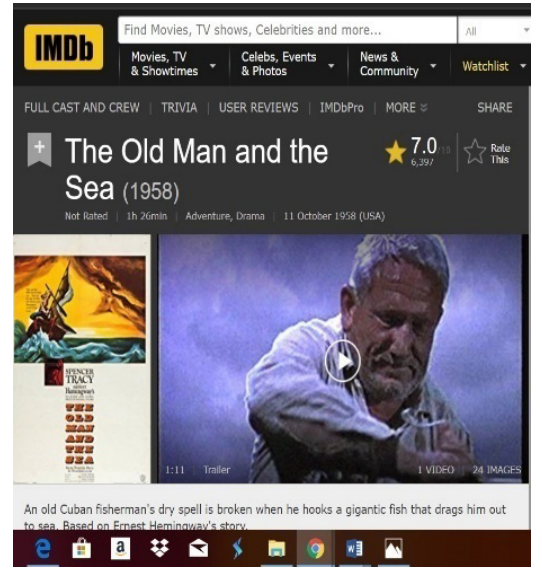

The Old Man and the Sea (1958) by John Sturges and Fred Zinnemann.

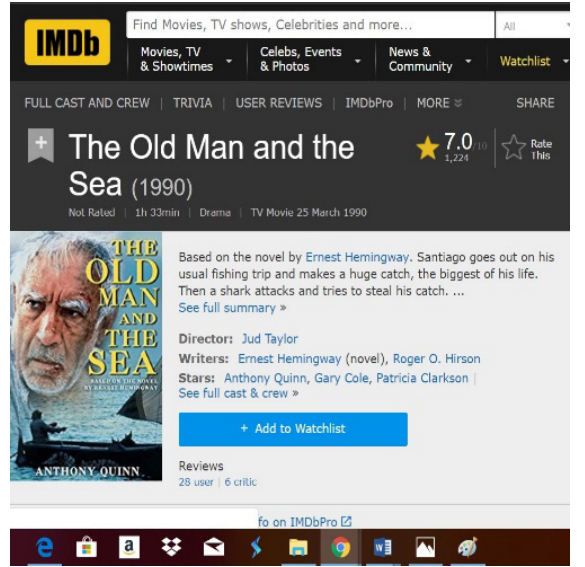

The Old Man and the Sea (1990) by Jud Taylor.

Figure 4: Screens shots: Movies of The Old Man and the Sea.

These films can be used as classroom resources while teaching the novel. Screening a few relevant clips from them in class and asking the students to watch the full movie outside the classroom hours can have a great effect on their understanding and enjoyment of the literary work. Using these wonderful digital resources freely available on the internet help the students visualize and thereby retain more details than by reading the printed novel and trying to visualize an unfamiliar setting. In addition to just watching films, many activities can be designed by teachers to engage students. The most common classroom activities that can be planned using a film are:

- Freeze frame viewing and commenting.

- Viewing and predicting.
- Viewing the full-length movie and reflection (on characters, theme, plot, and climax).

- Role-play.

- Viewing and writing reviews. The above activities using films can help in achieving the existing course objectives such as:

- Understanding the background information.

- Observing Characters.

- Guessing meaning from the context.

- Making inference.

- Listening for general ideas.

- Listening for specific information.

- Listening for key words and main ideas.

- Describing a situation. 
- Describing a series of actions.

- Making Predictions.

- Telling the whole story and stating opinions (James and Justin, 2008).

\section{Study Materials on the Internet}

Innumerable study materials are available on poetry, fiction, drama and even films online. These study materials include lesson plans, lesson notes, short term projects, classroom activities, images that support the understanding of a particular literary text and ready-made essays that help students to prepare for their exams. There are numerous websites that give free access to study materials free of cost. Some such commonly used websites are Study.com, Spark Notes, Google Images, a blog named The books
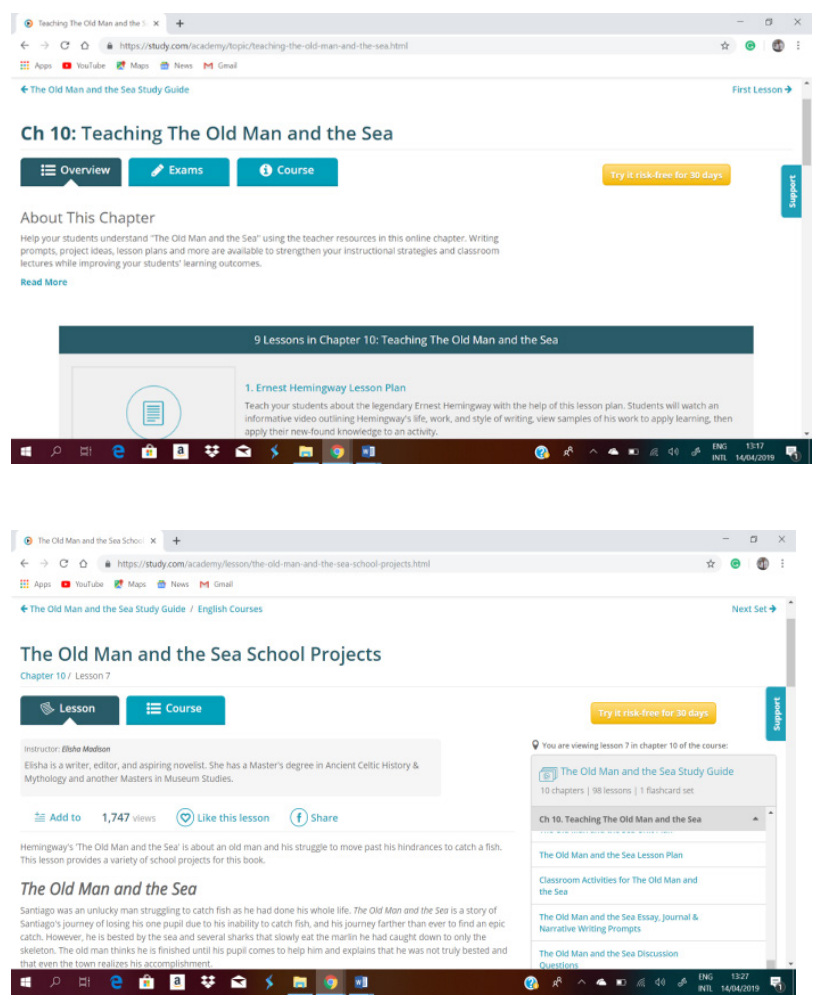

tell you why? etc. Teachers and students can access these materials online from anywhere, anytime and on any smart devices when they have internet connectivity. In order to make students use these valuable study materials, teachers should first be familiar with these resources and then they can filter the best of the resources and share links with their students to reduce time spent in browsing.

\subsection{Study.com}

The website study.com has plenty of study materials on the novel, The Old Man and the Sea. These materials include many topical discussions on the author and the text, lesson plans and teaching tips for teachers, suggestions for student projects and many classroom activities including quizzes that help students understand, study and test their knowledge of the novel.
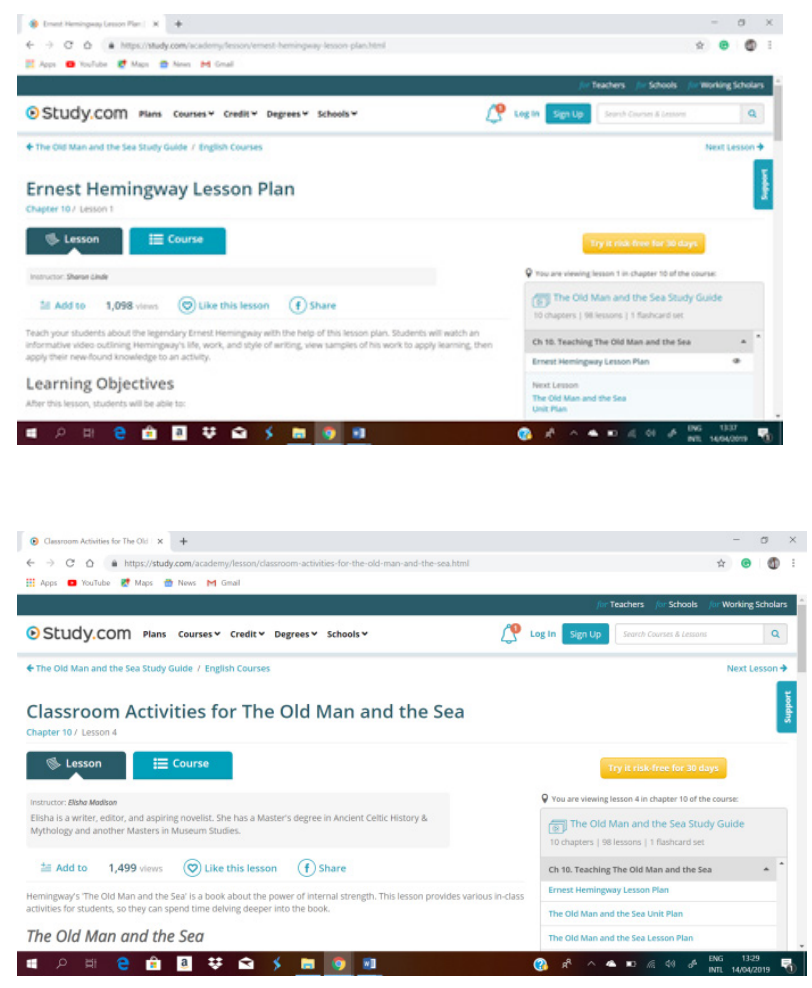

Figure 5: Screenshots: Study.com resources on The Old Man and the Sea.

\subsection{Google Images}

Google images is a very useful online web resource, which provides images on anything you ask for. There are hundreds of images available on The Old Man and the Sea and the author Ernest Hemingway. This online resource can be used to set the context, to create a background knowledge about the author, plot, characters and the setting. Teachers can make students explore this site further by assigning activities like digital poster preparation on various aspects of the novel and these posters can be used in class for further explanation, reiteration, and retention of details. 

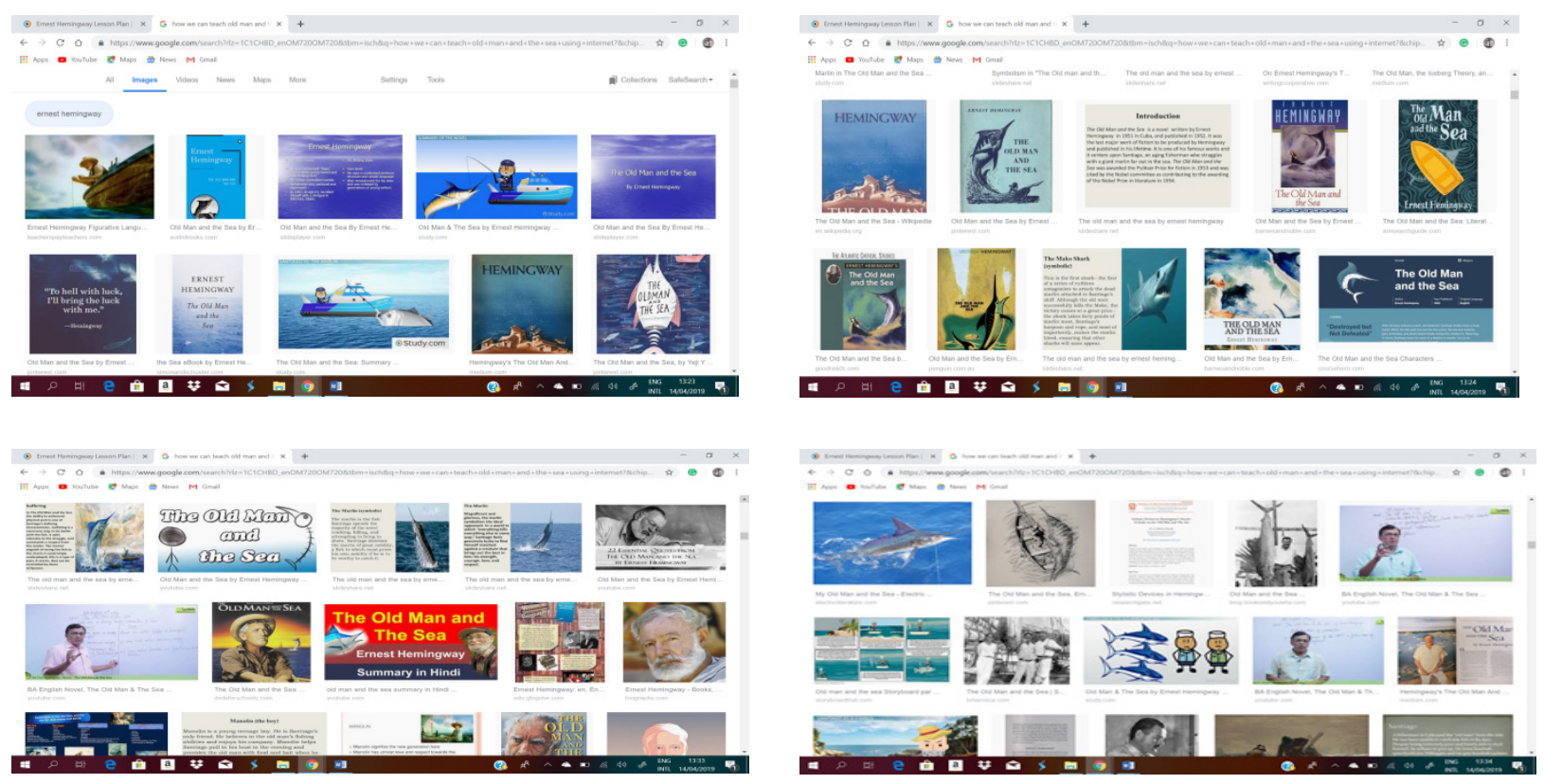

Figure 6: Screenshots - Google images on The Old Man and the Sea.

\subsection{Using Google Images to make Digital Posters}

The use of posters is one of the key strategies used in education down the ages that ensures effective teaching and learning. There are many advantages of using posters as a visual aid in the learning process. As stated in printimeposter.com, "posters can be an effective way to catch and hold the attention of students as well as maintain their interest in the subject. They can motivate students to learn a specific topic and help them focus on a certain idea, fact, or process that the teacher intends the students to learn". Images that are displayed through posters can be very evocative than words and lay the foundation of a variety of associations. Most of the people worldwide find learning most effective when it is transmitted visually and the poster is a powerful visual tool. Finally, by having a poster on a specific topic in the classroom, teachers induce students to constant learning. However, the success and the effectiveness of its use depend upon the proper selection and correct utilization of this graphic tool.

A teacher should be mindful of a few things while preparing a poster. The teacher should take the specific desired learning outcome into consideration while choosing and using visual elements in a poster. A good poster should be simple, brief, appropriate, attractive and colorful. The message must be understood at a mere glimpse and it should only contain a minimum number of words (say, in the form of captions) to help students understand the content and message illustrated. In addition, the images should correspond to the theme or subject that is discussed and they should have an appropriate size, design, and color. Teachers should do their best to help the students to pick up the message of a particular poster and carry it in their thoughts. There should be a logical sequence of images from the top to bottom of the poster so that they do not get confused. Digital posters can be easily made using Microsoft Word with images from Google images or from any other internet resources. These posters can be easily shared with students through emails and other common communication apps like WhatsApp or they can be printed and displayed in classrooms.

In a literature class, either the teacher can prepare a poster or students can prepare it following guidelines from the teacher. At times, poster making can be a part of the assessment. The class can be divided into groups and each group can be asked to prepare a poster on one aspect of the text they are learning. The teacher can provide the students with links to the web resources that they can refer to while collecting images for the poster. Each group can choose a theme and work on a poster and once the poster is ready they can display it in class and give a presentation explaining it to their peers. The poster and presentation can be assessed and marked. The poster preparation and presentation can enhance students' research skills and their speaking and presentation skills. To exemplify this point, four posters on four different themes on The Old Man and the Sea have been prepared by the author of this article 
and are appended: Poster 1 illustrates the life and work of Ernest Hemingway. Poster 2 depicts the life of Santiago, the protagonist. Poster 3 describes the flora and fauna featured in the novel. Finally, Poster 4 portrays Santiago's fishing journey and equipment. Similarly, many poster themes can be derived from the novel and distributed to students to prepare posters. This task will actively engage students in the learning process.

\subsection{Blog: Books Tell You Why}

Books Tell You Why is an edublog (a blog dedicated to education purposes) that is dedicated to discussing books. This blog has many resources that are helpful for teachers and students. The essay titled, What Lessons Can We Learn from The Old Man and the Sea? on the blog discusses the moral aspects of the novel. This edublog is a good resource for teachers and a valuable resource for students to prepare for exams.

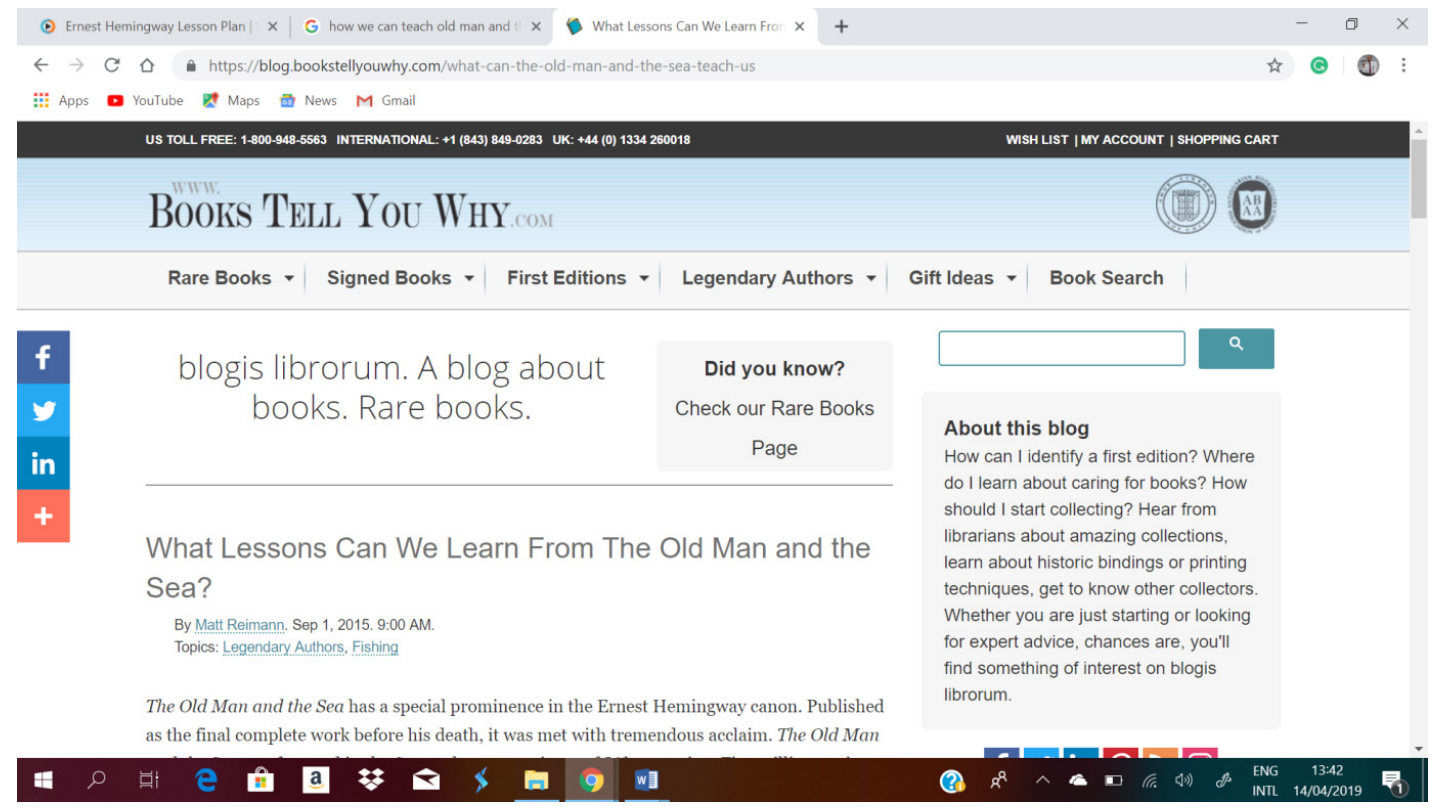

Figure 7: Screenshot: Essays on The Old Man and the Sea.
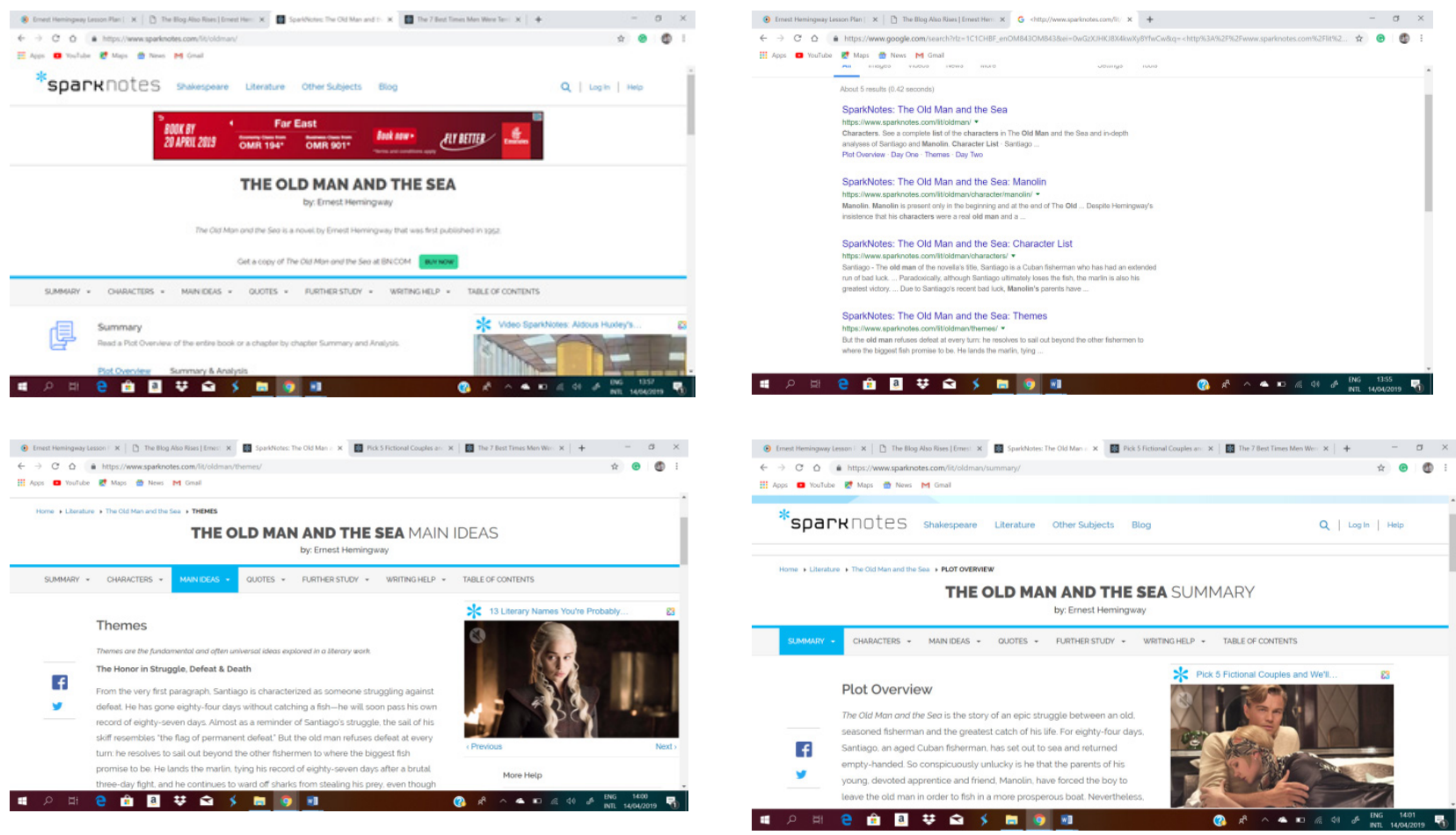

Figure 8: Screenshots: Spark notes: Notes on The Old Man and the Sea. 


\subsection{Spark Notes}

Spark notes is another valuable resource for students of English Literature. They have notes on almost all the authors they study about in their courses. These notes include plot summaries, analyses of characters and main ideas and important quotes from novels, model quizzes and writing help for students to write critical essays on literary works. Teachers can share the URL to useful pages from this site which students can easily refer to for their study purposes. The site makes it easy for teachers to prepare notes on the books they teach as the resources that are available here are as good as any teacher prepared notes and help reduce the preparation time of teachers.

\section{Conclusion}

ICT will continue to play a vital role in the world of education making teaching and learning processes smarter, easier, more exciting, productive and rewarding. When technology blends with teaching practices, students will be better motivated and engaged. Teaching can become more student-centred as students participation is enhanced by the e-resources, which match their interest and learning style. In addition, technology equips them better to collaborate with teachers and peers inside and outside classrooms.

To make teaching literature in this digital world a success story, it is incumbent on teachers to constantly update their technical skills and keep abreast with the changes that are happening in the world of education in approaches and practices in the rest of the world. AbdAlla observes, "the result of technology-based teaching and learning of literature manifests great contribution of student-centred strategies in developing their autonomy and motivating as well as engaging them in the learning process" (2017). Incorporating ICT and innovative blended learning strategies in current teaching practices will make teaching and learning Literature more learner-fronted, interesting and stimulating and above all viable and relevant to the times.

\section{About the Author}

Justin James M.A., M.Phil., Cert.ICT (Trinity), TESOL is an English Lecturer cum E-Learning Coordinator at English Language Center, Nizwa College of Technology. $\mathrm{He}$ is also a teacher trainer specialized in training EFL/ ESL teachers in teaching English using technology. He specializes in teaching English language skills through Information Communication Technology.

\section{Acknowledgment}

I wish to acknowledge that this paper drew heavily on the materials and facilities available at the English Language Center, Nizwa College of Technology. I offer my sincere thanks to Mr. Sultan Al-Dighaishi, HoD, ELC, NCT for his constant encouragement and support. This note of thanksgiving would be insincere if I fail to appreciate the great help that I received from Mrs. Lalitha Justin, Lecturer, ELC, NCT in editing this paper and Dr. A. Vanitha, Assistant Professor of English PG and Research Department of English, Vellalar College for Women (Autonomous), India for accepting to publish this article in the College Journal.

\section{References}

1. AbdAlla, KMA. Technology integration in teaching literature. University of Khartoum, Khartoum, Sudan. 2017. Available from: https://journals.sfu.ca/vict/index.php/vict/article/ viewFile /242/120 on 14th April 2019.

2. Mangish A. The Old Man and the Sea Critical Review. 23 March 2019. Available from: https://www.slideshare.net/ spidymanjish/the-old-man-and-the-sea-review-ppt.

3. Apple. Apple classroom of tomorrow today 2: Learning in the twenty-first century. 2008. 05 April 2019. Available from: http://ali.apple.com/acot2/global/files/ACOT2_Background. pdf.

4. Uman B. The Old Man and The Sea as a tragedy. 2011. 23 March 2019. Available from: https://www.slideshare.net/ umabhaliya/1303bhaliyauma.

5. Blurton C. Directions of ICT Use in Education. 2002. 14 April 2019. Available from: https://www.unesco.org/education/ educprog/lwf/dl/edict.pdf.

6. Daves L. What stops teachers using new technology? M. Leask, Issues in Teaching Using ICT. p. 61-79; 2001. London: Routledge. PMid: 22312930. https://doi. org/10.4324/9780203185117-5.

7. Dewey J. The Child and the Curriculum. Edition illustrated reprint, ISBN 1360700501, 9781360700502). Wentworth Press: London; 2016.

8. Quazi F. The Old Man and The Sea Book Review. 2017. 23 March 2019. Available from: https://www.slideshare.net/ FaheemQazi2/the-old-man-and-the-sea-book-review.

9. Fisher A. The Old Man and Sea Advanced Exam Preparation. 2010. 23 March 2019. Available from: https:// www.slideshare.net/andyfisher/the-old-man-and-thesea-exam-preparation?qid=9ad59b1e- cfa2-4a1a-9367-c $08 \mathrm{f} 96 \mathrm{cc} 0 \mathrm{c} 4 \mathrm{c} \& \mathrm{v}=\& \mathrm{~b}=\&$ from_search $=1$.

10. Flavia. Teaching and studying literature in the digital era From Text to Hypertext. KABA University of Tirana, Foreign Languages Faculty, Spanish Language Department. 2017. 28 March 2019. Available from: http://dergipark.gov.tr/download/article-file/354651. 
11. Google Images. Available from: https://www.google.com/ search?rlz=1C1CHBF_enOM843OM843\&q=pins+on+the+ old + man + and + the + sea\&tbm $=$ isch\&source $=$ univ\&sa $=X \& v e$ d=2ahUKEwjs556ErtbhAhWF-6QKHV6zAAQQsAR6BAgJ EAE\&biw $=1280 \& b i h=578$.

12. Justin J, Lalitha J. Integrated skills development through authentic films. Proceedings of the 8th ELT Conference. Sultan Qaboos University Language Centre: Oman; 2008. p. 113-20.

13. Frank SK, Jukes I, McCain Ted DE, McCain Ted DE. Teaching the digital generation: No more cookie-cutter high schools. Michael Hinojosa Republished in Australia by Hawker Brownlow Education; 2009.

14. Koskimaa R. The challenge of Cybertext: Teaching literature in the digital world. 2007. 23 March 2019. Available from: https://www.uoc.edu/uocpapers/4/dt/eng/koskimaa.pdf.

15. Light D. The role of ICT in enhancing education in developing countries: Findings from an evaluation on the Intel Teach Essentials Course in India, Turkey and Chile. Journal of Education for International Development. 2009; 4(2):52-6.

16. Scher L. The Old Man and the Sea. Linkedin SlideShare. 2011. 23 March 2019. Available from: https://www.slideshare.net/ linkedin.

17. Petrov A. The Old Man and the Sea: Animation. 1999. 24 March 2019. Available from: https://www.youtube.com/ watch?v=W5ih1IRIRxI.
18. Prensky M. Digital natives, digital immigrants. On the Horizon (MCB University Press. 2001 Oct; 9(5). 2019. 12 April 2019. Available from: https://www.marcprensky.com/ writing/Prensky\%20-\%20Digital\%20Natives,\%20Digital\%20 Immigrants\%20-\%20Part1.pdf.

19. Printmeposter.com. 12 April 2019. Available from: https:// printmeposter.com/blog/the-use-of-posters-in-education/.

20. Saunders DJ. Visual communication handbook: Teaching and learning using simple visual materials. London: United Society for Christian Literature; 1974.

21. Sturges J, Zinnemann F. The Old Man and The Sea: Film. 1958. 24 March 2019. Available from: https://www.imdb. com/title/tt0052027/?ref_=fn_al_tt_4.

22. Scheer AC. Teaching English to Digital Natives: Harnessing the power of socialnetworks and Information and communication technology. (Thesis). 2012. 17 April 2019. Available from: https://portal.education.lu/inno/PUBLICATIONS/ Travaux-de- candidature/ArtMID/3717/ArticleID/523936/.

23. The Old Man and The Sea: Film. 24 March 2019. Available from: https://www.imdb.com/title/tt0052027/?ref_=fn_al_ tt_4.

24. Taylor J. 1990. 24 March 2019. Available from: https://www. imdb.com/title/tt0100288/?ref_=tt_rec_tt.

25. Tapscott D. Grown up digital: How the net generation is changing your world. New York: MacGraw Hill; 2009. 


\section{Appendix I - Poster 1}

The author of The Old Man and The Sea Ernest Hemingway and His Life Hemingway, the Writer.
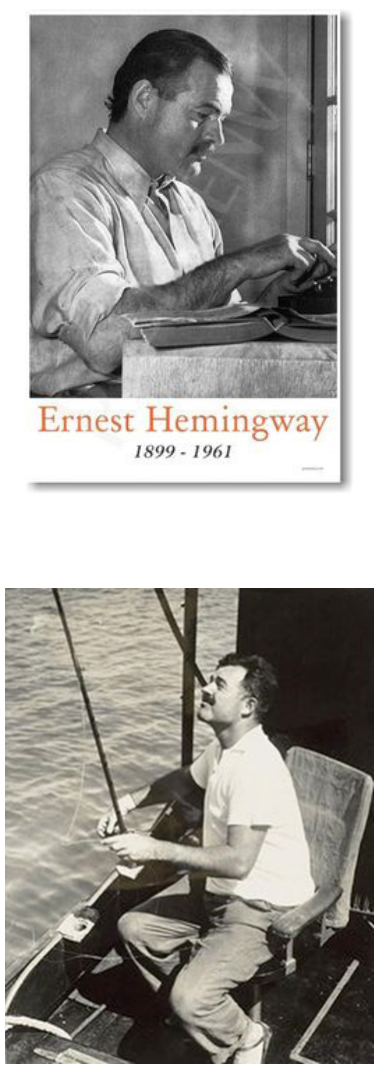

Hemingway casting his fishing line

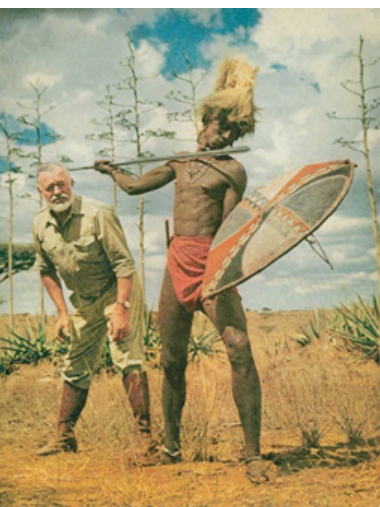

Hemingway with an African tribal hunter
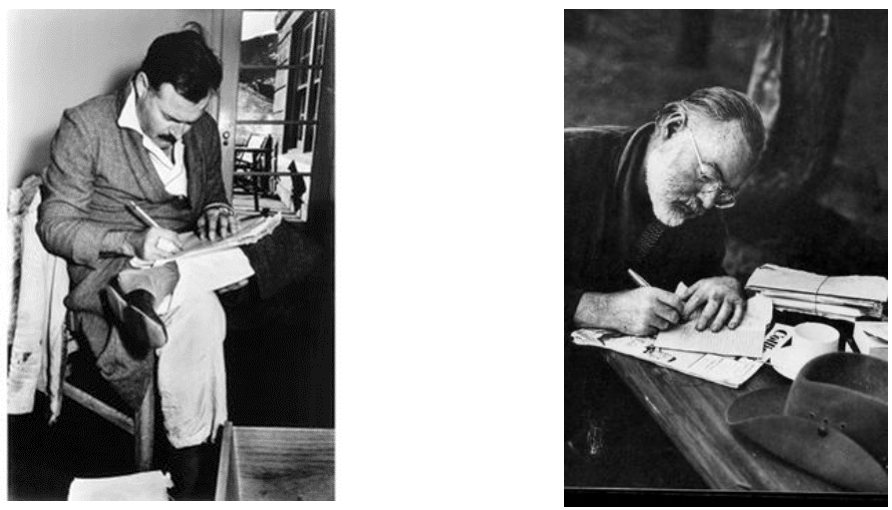

Hemingway, the Fisherman

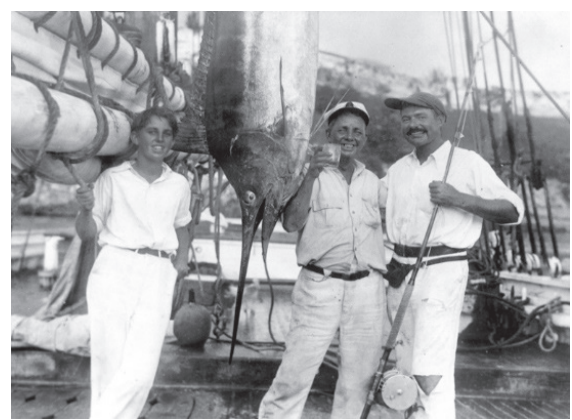

Hemingway on his boat Pillar with the blue marlin he caught

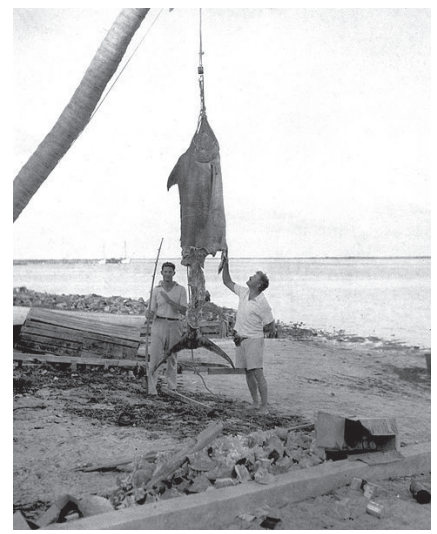

Hemingway and Mike Stater with the remains of the marlin that was eaten by sharks in the Bahamas in 1935.

\section{Hemingway, the Hunter}
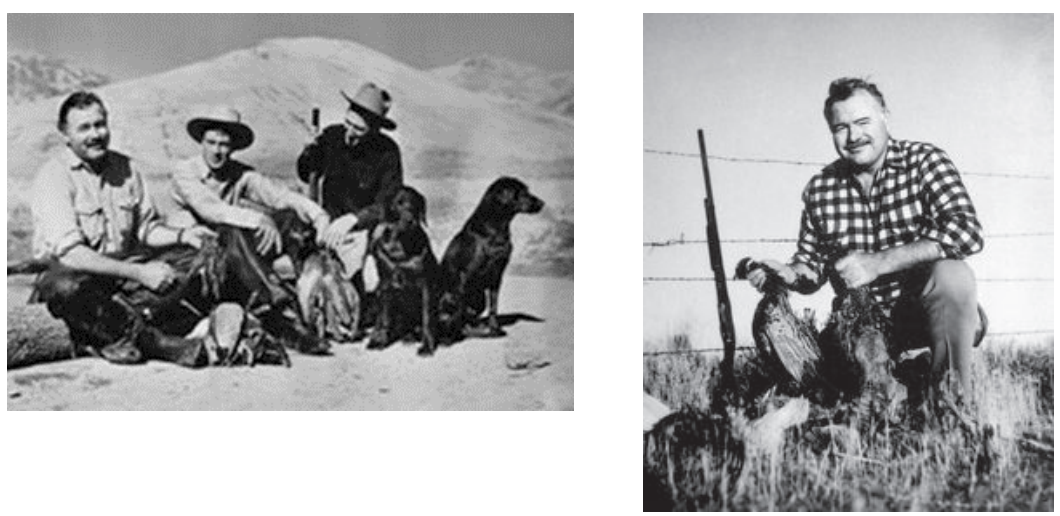

Hemingway with his fellow hunters and Hemingway hunting fowl their dogs in Africa.

\section{Google Images. Retrieved from}

https://www.google.com/search?rlz=1C1CHBF_enOM843OM843\&q=pins+on+the+old +man+and+the+sea\&tbm=isch \&source $=$ univ \&sa $=$ X\&ved=2ahUKEwjs556ErtbhAhWF-6QKHV6zAAQQsAR6BAgJEAE\&biw $=1280 \&$ bih $=578$ on April 17, 2019 


\section{Appendix II - Poster 2}

The Old Man and the Sea Poster 3 - Santiago's Lifestyle

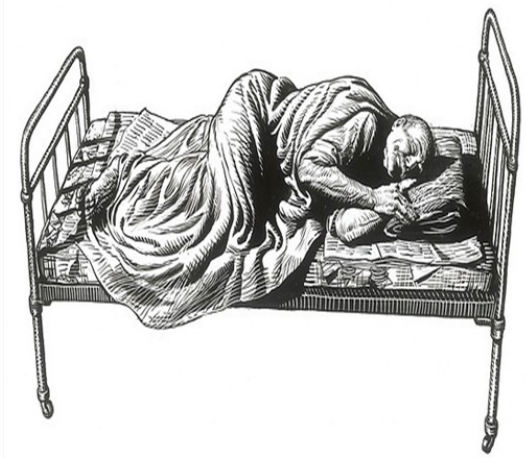

Santiago sleeping on his cot

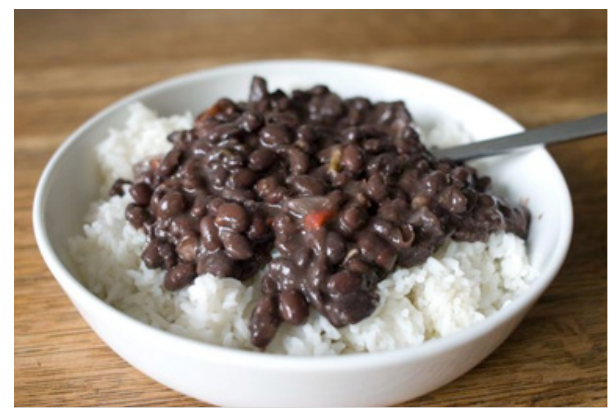

Black Beans and Rice

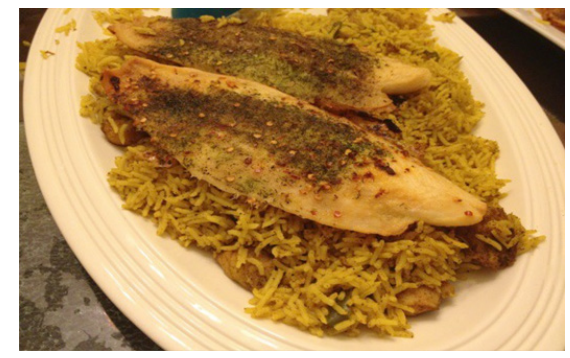

Santiago's dream food

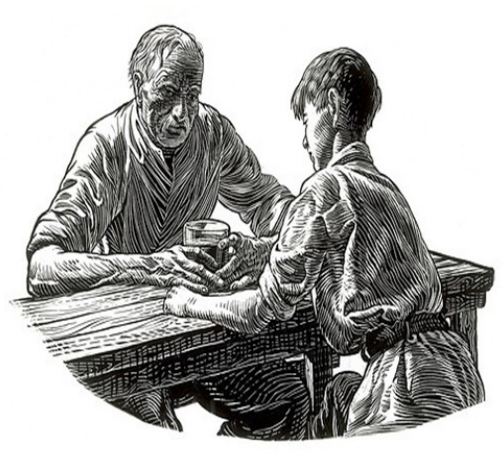

Santiago sitting on the terrace with Manolin and talking about baseball.

The food that Santiago eats

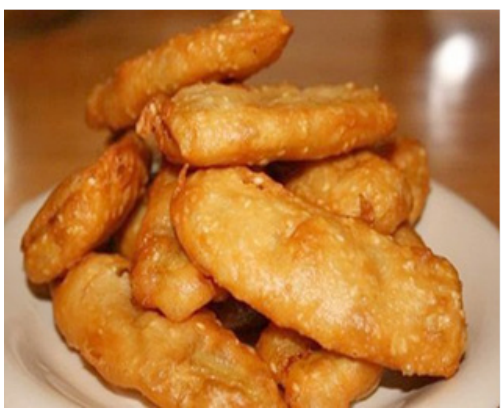

Fried Banana

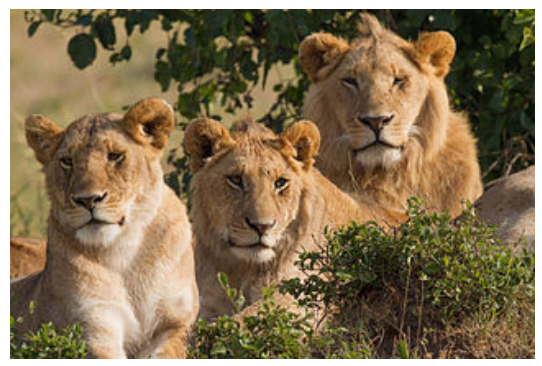

Santiago's lions on the African coast in his dreams.

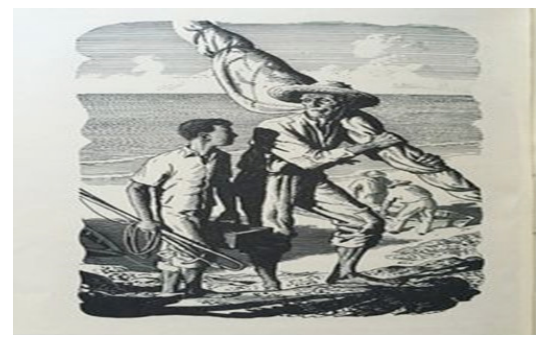

Santiago going for fishing accompanied by Manolin

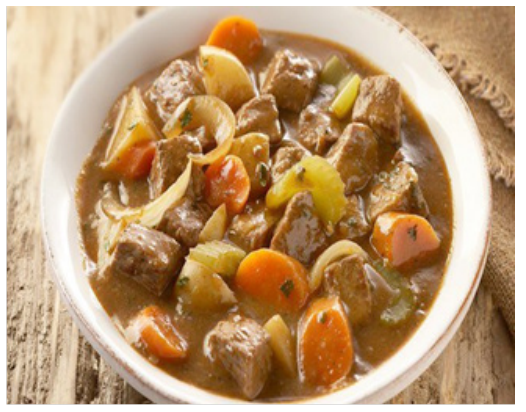

Stew

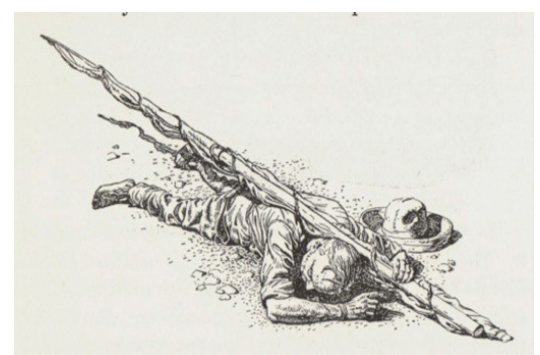

Santiago lying on the beach tired and defeated after his struggle to bring the Marlin to the shore.

Google Images. Retrieved from

https://www.google.com/search?rlz=1C1CHBF_enOM843OM843\&q=pins+on+the+old+man+and+the+sea\&tbm=isch\& source $=$ univ\&sa $=$ X\&ved=2ahUKEwjs556ErtbhAhWF-6QKHV6zAAQQsAR6BAgJEAE\&biw=1280\&bih=578 on April 17, 2019 


\section{Appendix III - Poster 3}

The Old Man and the Sea Poster 2 - Flora and fauna featured in the Novel

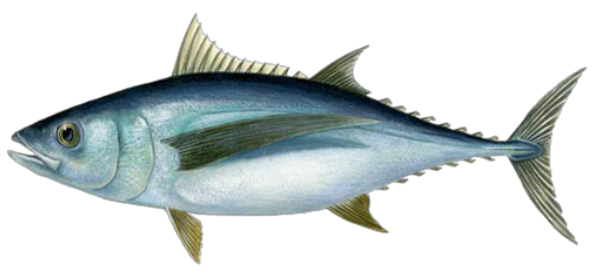

Tuna Albacore

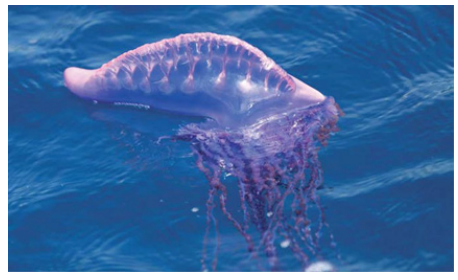

Portuguese Man of War or Blue

Terror or Blue Bottle

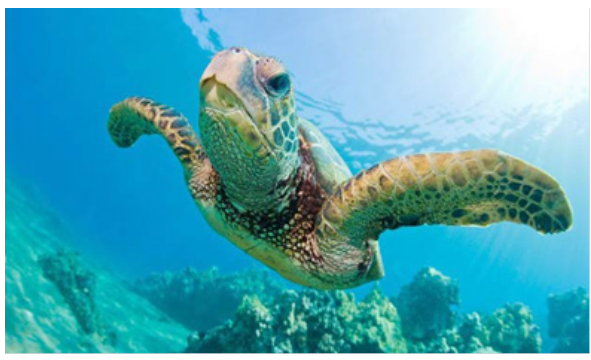

Sea Turtle

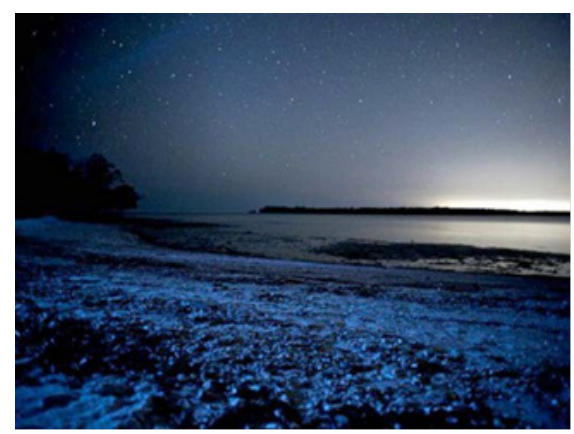

Phosphorescent

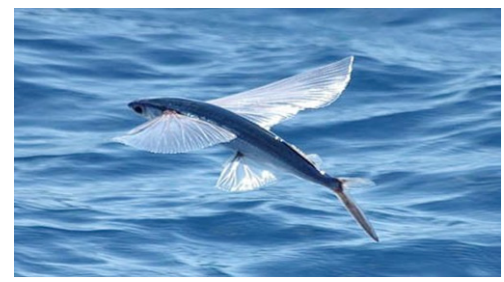

Flying Fish

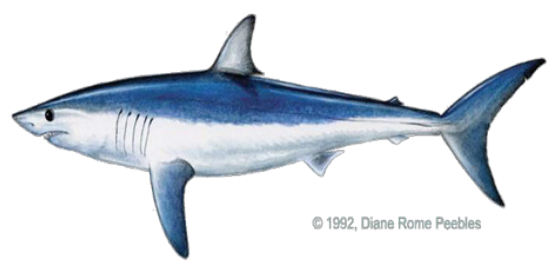

Mako Shark

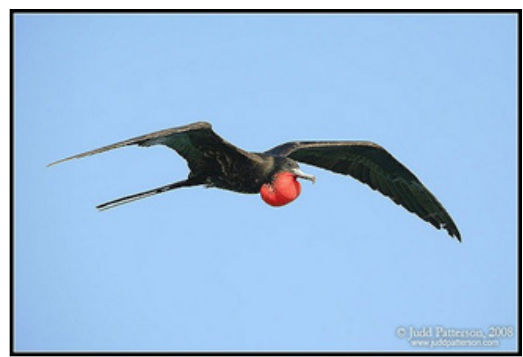

Man of War or Frigate Bird

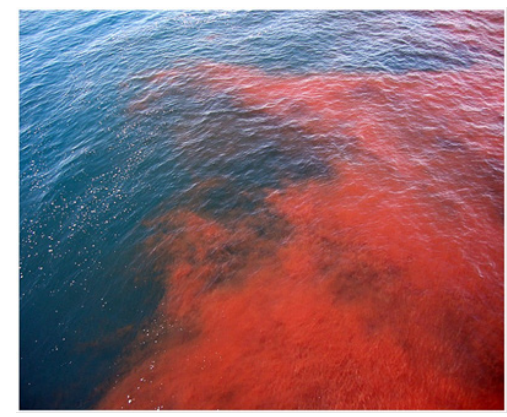

Red Algal Bloom

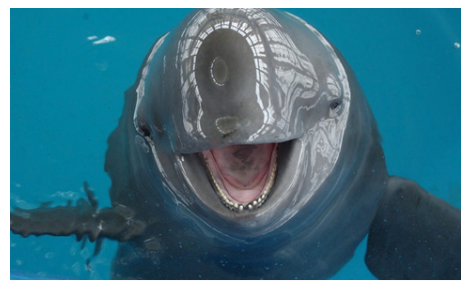

Porpoise Dolphin

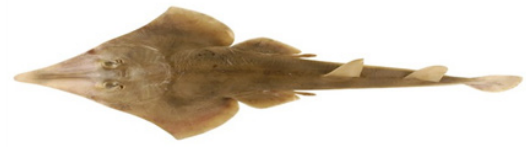

Shovel Nosed Shark

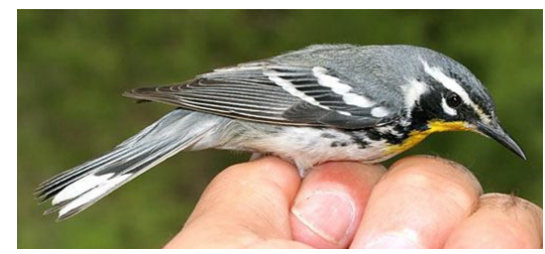

Warbler Bird

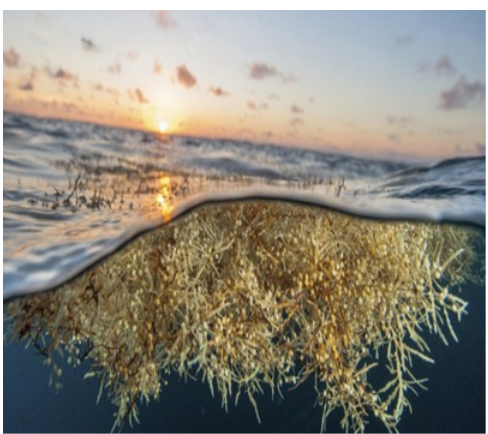

Sargasso Weed

Google Images. Retrieved from

https://www.google.com/search?rlz=1C1CHBF_enOM843OM843\&q=pins+on+the+old+man+and+the+sea\&tbm=isch\& source $=$ univ\&sa $=$ X\&ved $=2$ ahUKEwjs556ErtbhAhWF-6QKHV6zAAQQsAR6BAgJEAE\&biw=1280\&bih=578 on April 17, 2019 


\section{Appendix IV - Poster 4}

\section{The Old Man and the Sea Poster 1}

Santiago's Fishing Journey and Equipment

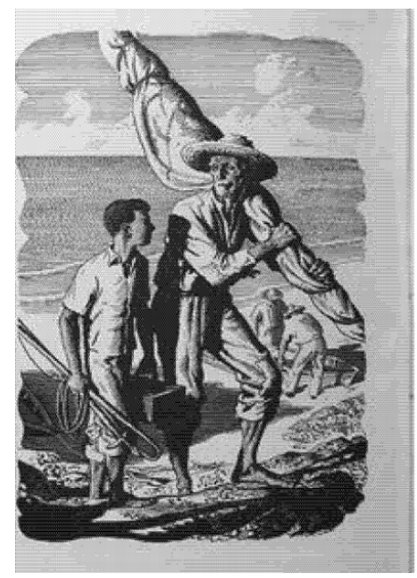

Manolin seeing off Santiago who is out for fishing alone.

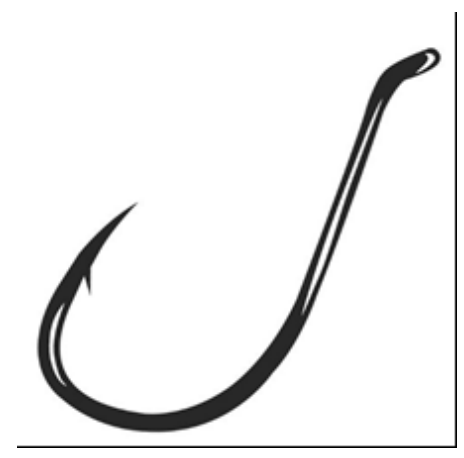

The hook used for baiting the Marlin.

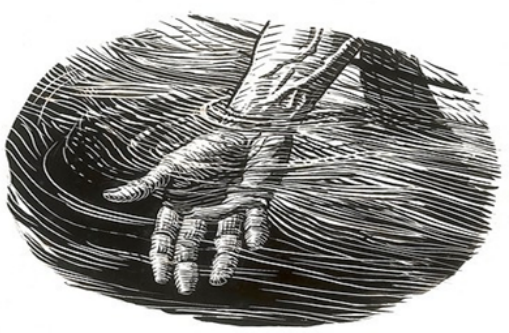

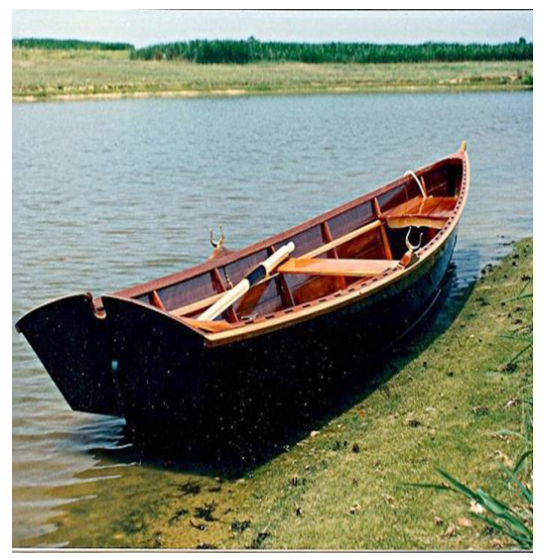

Santiago's skiff - the small boat in which Santiago goes out fishing.

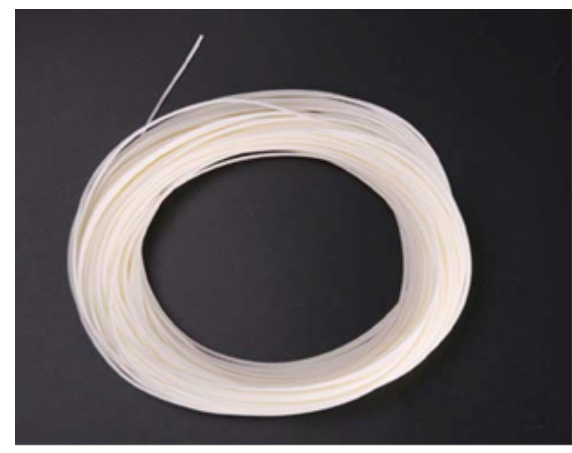

The line used to tie the hook.

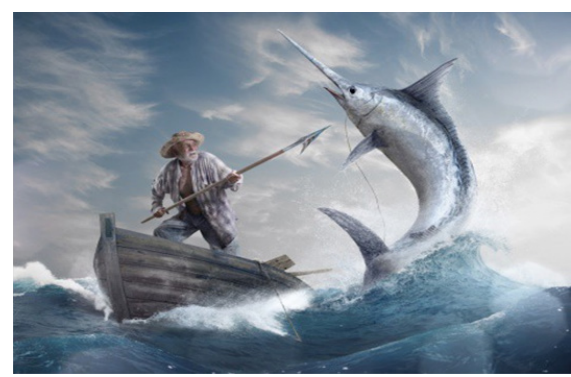

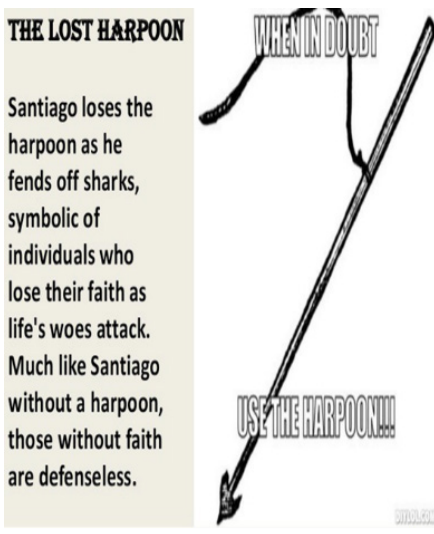

The harpoon used by Santiago

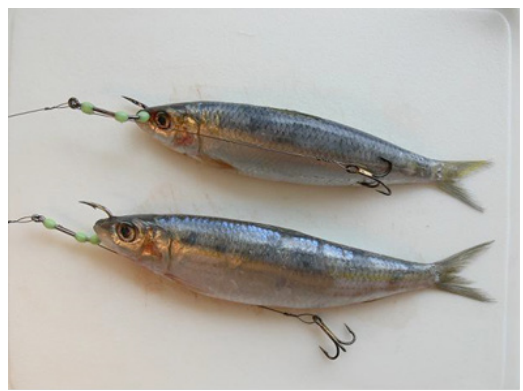

The Sardines that are used as the bait.

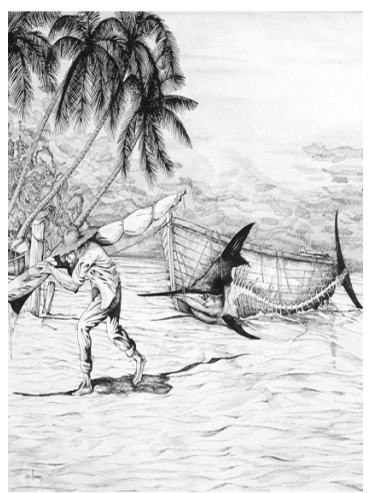

Santiago returning after fishing with the skeleton of the Shark eaten Marlin. Santiago washing his bleeding han
which was cut by the fishing line.

Santiago harpooning the Marlin.$$
\text { which was cut by the fishing line. }
$$

Google Images. Retrieved from

https://www.google.com/search?rlz=1C1CHBF_enOM843OM843\&q=pins+on+the+old+man+and+the+sea\&tbm=isch \& source $=$ univ\&sa $=$ X\&ved=2ahUKEwjs556ErtbhAhWF-6QKHV6zAAQQsAR6BAgJEAE\&biw=1280\&bih=578 on April 17, 2019 